\title{
The Trinity - God, Federation, and Community: A Mixed-Methodological Analysis of Religion and Ethnicity among the Shack Dwellers Federation of Namibia
}

\begin{abstract}
Angela Cowser ${ }^{1} \&$ Sandra L. Barnes ${ }^{2, *}$
${ }^{1}$ Louisville Presbyterian Theological Seminary, 1044 Alta Vista Road, Louisville, KY, 40205-1798, USA

${ }^{2}$ Vanderbilt University, Peabody \#90, 230 Appleton Place, Nashville, TN 37203-5721, USA

*Corresponding author: Vanderbilt University, Peabody \#90, 230 Appleton Place, Nashville, TN 37203-5721, 615-322-8714, USA. Tel: 615-322-1141. E-mail: sandra.1.barnes@vanderbilt.edu
\end{abstract}

Received: July 8, 2019 Accepted: August 10, 2019 Published: January 23, 2020

doi:10.5296/jsr.v11i1.16387ＵRL: https://doi.org/10.5296/jsr.v11i1.16387

\begin{abstract}
How are religious involvement and community-mobilizing related for poor Namibian women? This mixed - methodological study examines the influence of ethnicity, attitudinal, and behavioral traits on religious affiliation and related experiences for 258 female members of the Shack Dwellers Federation of Namibia, a network of neighborhood-based savings groups that attempts to provide affordable housing and related infrastructure services to poor women. In addition to its practical benefits, we consider whether the Federation represents a proxy-church for members. We assess the following research questions: With which churches are Federation women affiliated? Do their ethnicities or views and decisions about the Federation affect their religious ties? Do results suggest that the Federation provides outcomes commonly associated with churches? Results based on statistical and content analyses illustrate differences in religious affiliation and experiential variations based on ethnicity as well as church-like benefits of Federation involvement.
\end{abstract}

Keywords: poverty, religious ties, para-religious organizations, women-centered mobilization 


\section{Introduction}

The Shack Dwellers Federation of Namibia (SDFN) is a network of neighborhood-based savings groups designed to provide affordable housing, land, and related infrastructure services across thirteen Namibian regions. The majority of members (also known as Federasi) are extremely impoverished women with children who join to build their own brick houses to escape the shacks in which they live (Cowser, 2013; Cowser \& Barnes, 2016; Hishongwa, 1983; Iipinge \& Lebeau, 2005; Iken, 1993). Most Federasi are affiliated with local churches. Yet churches have had minimal involvement historically in combating poverty in Namibia. Do poor Namibian women's congregational and Federation ties influence each other and, if so, how? Moreover, do these religious affiliations differ for various ethnic groups? Informed by existing literature on religious life in Namibia (Buys \& Nambala, 2003; Loubser, 1987; Totemeyer, 2010), this study assesses the experiences of 258 female Federasi about their religious affiliations and some of the demographic and experiential traits that influence these ties as well as narratives about their Federation experiences. Bivariate, multinomial logit regression, and content analyses are used to answer four research questions. What religious affiliations do Federation women have? Do religious ties vary by ethnicity and other characteristics such as education, Federation tenure, and organizational beliefs? Do their narratives help illumine religious and Federation ties? Lastly, is there evidence to suggest that the Federation represents a proxy-church? These findings have academic and applied import. First, they will help better understand how, despite daily exposure to poverty rates as high as $76 \%$, secular organizations such the Federation may help poor Namibian women become more adaptive and resilient. Results extend anecdotal and the limited qualitative research on this topic (Buys \& Nambala, 2003; Cowser \& Barnes, 2016; Iken, 1993). Federasi best practices may help mobilize other poor groups and scaffold religious ties. Lastly, to our knowledge, this is the first mixed-methodological study on this topic.

\section{Poverty and the Shack Dwellers Federation of Namibia}

According to 2015 United Nations Development Programme statistics, Namibia has poverty rates as high as $76.0 \%$ (UNDP, 2015). Women and children are particularly vulnerable and often experience limited social services, healthcare, vocational training, and social services. The poor tend to lack political protections and do not receive basic goods and services (lipinge \& Lebeau, 2005; Paxton \& Hughes, 2014). Moreover, Namibian shack dwellers contend with: economic instability; inadequate food; poor-quality, hazardous, and overcrowded housing; lower school attendance among their children; poor public infrastructure; and, increased child labor. Given widespread unemployment and declining wages among Namibian men, women's earnings are often the main source of livelihood for many households. Women tend to work in the informal economy in female-focused networks where they sell goods and services that are extensions of their domestic roles (lipinge \& Lebeau, 2005; Iken, 1993). Despite these chronic negative conditions and subsequent group organizing, research on this subject is limited. 
Founded in 1992, the Shack Dwellers Federation of Namibia is a network of neighborhood-based savings groups located in informal settlements (i.e., shack dwellings, squatter settlements or shantytowns). The Federation was created by the Namibian Housing Action Group (NHAG) that helps local and regional communities organize their own membership-based organizations or MBOPs. The organization consists of over 200 self-help groups. As of 2015, 22,000 households are members and a reported 3,500 homes have been built (Shack Dwellers News, 2016; worldhabitatawards.org, 2015). Moreover, households organized into 605 groups have collectively saved over N\$13 million. About $90 \%$ of Federasi are female. For most women, Federation participation represents the possibility to move from dirt-floor shacks into their own brick homes (Chen et al, 2007; Cowser, 2013; Hishongwa, 1983). Federasi join voluntarily, work together to achieve collectively defined objectives, and provide in-kind contributions of labor and time (i.e., sweat equity) to build new homes (Chen et al., 2007; Cowser \& Barnes, 2016). The Federation focuses on the following activities: building homes; savings groups for communal safety nets; practical training and education to cultivate strong work ethics; information sharing during community exchanges; (note 1) political action; developing settlement profiles; (note 2) negotiating for affordable land, infrastructure, and resources; and, acquiring loans to establish small business and purchase houses. (note 3) It is common for Federasi women to mobilize their assets and kinship networks (Cowser, 2013; Smock, 2004; Stall \& Stoecker, 1997). The Federation also cultivates democracy, relationship - building, and leadership (Bystydzienski \& Sekhon, 1999; Chen et al, 2007; Christens, 2010). Overall, the Federation is a direct response to the disproportionate percentage of poor, largely female Namibians, their children, and the elderly who have been systematically excluded from commercial housing and financing processes. This study considers correlates between religious and Federation ties.

\section{Religion, Race, and Gender in Namibia: Guiding Framework}

Rather than a traditional theory, this analysis is informed by a broad scholarly framework that considers the history, context, and effects of religion in Namibia, particularly for Federasi. This summary does not do justice to this history, but endeavors to provide a broad context for this study. Indigenous religions in Namibia historically focused on a Supreme Being, humanity as stewards of God's creation, and ancestor worship. But as early as the mid-1600s, missionaries from the Dutch Reformed Church brought with them both Christianity and apartheid theology/ideology. Church planting was most common during the pre-colonial $19^{\text {th }}$ century as other Europeans arrived such as the Rhenish Mission in 1820 out of which the Lutheran Church in Namibia was formed. Missionary zeal also influenced Namibia socially, economically, and politically. Colonialism and related unrest were linked to events such as the German-Herero War in 1904 and World War I. Counter-resistance by native Namibians informed the rise of Liberation Theology, particularly in the predominately black Evangelical Lutheran Church in the Republic of Namibia (ELCRN) and spearheaded by Bishop Zephania Kameeta. Other denominations such as: Roman Catholics in the late 1890s; Baptists and Seventh Day Adventists in the 1910s and 1920s; Pentecostal churches in the 1940s and 50s; and, non-denominational churches since 1990, illustrate transitions from traditionalism to 
more varied religious expressions and self-dependency (Buys \& Nambala, 2003; Loubser, 1987; Totemeyer, 2010).

Namibian women have been involved in churches historically. However, the legacy of apartheid shaped religious spaces and, with the exception of the historic Council of Churches in Namibia (CCN), an ecumenical coalition of Christian denominations designed to address the spiritual and temporal needs of Namibians in general and poor Namibians in particular, church-based efforts to help the poor were uncommon (Buys \& Nambala, 2003; Cowser, 2013; Loubser, 1987; Totemeyer, 2010). Although the majority of white, English-speaking churches did not embrace apartheid in theory, they accepted it in practice. (note 4) Yet most mainline churches in South Africa and Namibia, most notably black Reformed, Roman Catholic, Anglican, Methodist, and Lutheran congregations, denounced apartheid and espoused unconditional love, community, as well as the God-given value and dignity of black identity. Today, $90 \%$ of Namibians belong to a Christian denomination such as; Lutheran (48\%), Roman Catholic (32\%), Dutch Reformed and United Reformed (10\%), Anglican (8\%), and Methodist (2\%). Smaller, independent African churches include the Oruaano Protestant Unity Church (Buys \& Nambala, 2003).

Inter-denominational women's circles existed for many years that organized: prayer and Bible study; visitation of the elderly, sick, homeless, and unemployed; and, missions fundraising. However, circle leaders were rarely poor, indigenous women, but rather missionary wives and wives of chiefs. According to Buys and Nambala (2002), women; "...were more trustworthy in worship and congregational activities than their male counterparts... it was the women who led Circles and other women's societies, supporting the work of the church in many fields of ministry" (Pp. 266-70). Women hold leadership roles in Pentecostal and other more charismatic churches (Loubser, 1987; Totemeyer, 2010) and remain central to the viability of most churches (Buys \& Nambala, 2003). Although less common than the aforementioned churches, Mainline churches herald women leaders; such leadership presence is rare among Roman Catholics. (note 5)

Some scholars posit that, in addition to house building, many Federasi join the organization because it meets crucial needs absent in local churches such as safety, funding, and training (Cowser \& Barnes, 2016; Iken, 1999). The two largest denominations in Namibia and among Federasi today, the black Lutheran and Roman Catholic churches, focus their efforts on HIV/AIDS, educational, and medical programs. However, local denominations are economically, ideologically, and ecclesiological distinct from the Federation (Buys \& Nambala, 2003). Furthermore, most congregations espouse an apolitical theology that encourages adherents to focus on strict piety, church attendance, and internal volunteerism, rather than community action. Separation of Church and State is emphasized (Buys \& Nambala, 2003; Cowser, 2013). Yet the Federation is mobilizing human and economic reserves to combat poverty and improve housing policy. Given these dynamics, do Federasi act as a de facto political arm of local black churches? Can an argument be made that the Federation is a proxy-church? Are ties between this collective and religious organizations evident empirically for Federasi? 


\subsection{Hypotheses and Summary Justifications}

Based on the above literature and framework, this project examines whether ethnicity as well as other demographic and experiential indicators affect religious affiliation among Federasi. In addition to controlling for education (note 6) and Federation tenure, we assess six hypotheses. (note 7)

Ethnicity: Federasi religious affiliations will vary by ethnicity.

H1: Women who are Nama-Damara are more likely to be affiliated with Pentecostal, Apostolic, and Gospel religious traditions more than Mainline and Roman Catholic traditions as compared to women from other ethnic groups.

H2: Women who are Oshiwambo or Otjiherero are more likely to be affiliated with mainline traditions than Pentecostal, Apostolic, and Gospel or Roman Catholic traditions as compared to women from other ethnic groups.

H3: Women who are colored and speak Afrikaans (note 8) are more likely to be affiliated with the Roman Catholic tradition than Pentecostal, Apostolic, and Gospel or Mainline traditions as compared to women from other ethnic groups.

Behavioral Motivations: Federasi religious affiliations will vary by behavioral indicators.

H4: Women who joined the Federation specifically to build a brick house are more likely to be affiliated with Pentecostal, Apostolic, and Gospel religious traditions than Mainline or Roman Catholic traditions as compared to women who joined for other reasons.

H5: Women who joined the Federation specifically to build community are more likely to be affiliated with mainline religious traditions than Pentecostal, Apostolic, and Gospel or Roman Catholic traditions as compared to women who joined for other reasons.

Attitudes: Federasi religious affiliations will vary by attitudinal indicators.

H6: Women whose consider the Federation an organization to unify and mobilize the poor are more likely to be affiliated with Mainline religious traditions than Pentecostal, Apostolic, and Gospel or Roman Catholic traditions as compared to women who associate the organization with more individual-level outcomes.

When we consider our two control variables, studies show that in Namibia, educational attainment for poor blacks is limited and focuses on domestic roles for females and gardening for males. Post-Bantu completion (through Standard 10 and somewhat comparable to grades 8-12 in the United States) is the highest level of completion. Thus we predict that Federasi who have achieved this educational level are more likely to be affiliated with Roman Catholic traditions that tend to attract urbanites as well as persons who are from more elite families and relatively more economically stable (Cowser, 2013; Hishongwa, 1983; Iipinge \& Lebeau, 2005). We also anticipate women with longer Federation tenure will be Catholic largely for the same reasons.

Central to this study is the possible influence of ethnicity on religious ties. Given that, to our 
knowledge, this topic has not been examined before using quantitative analyses, a certain dimension of our tests is exploratory. However, anecdotes and qualitative studies inform our expectations. First, the relatively longer involvement in the Federation among some Nama-Damara women as well as women's ability to take on leadership roles in Pentecostal, Apostolic, and Gospel more concertedly than in other religious traditions suggest that Federasi from these two ethnic groups might be drawn to these more charismatic, less hierarchical congregations (Hypothesis 1) (Buys \& Nambala, 2003; Cowser, 2013; Loubser, 1987; Totemeyer, 2010). Next, involvement in the anti-apartheid movement by mainline churches that are connected to the Otjiherero support our second hypothesis (Cowser, 2013). Albeit limited, qualitative research and anecdotes suggest that black Namibian women who: live in urban spaces; are designated Colored and primarily speak Afrikaans due to their more frequent involvement with white Namibians; and, are often relatively more economically stable as compared to their counterparts, may be more likely to be affiliated with Catholicism (Cowser, 2013; Hishongwa, 1983; Iipinge \& Lebeau, 2005) (Hypothesis 3). Quantitative tests will show whether these hypotheses bear out.

Although the Federation was organized largely to combat poverty, respondents express and prioritize economic and non-economic reasons for joining as well as when describing the collective. Our final three hypotheses consider the possible effects of how Federasi prioritize these motivations and actions. Because Pentecostal, Apostolic, and Gospel churches have tended to attract the most impoverished women, we expect the Federasi who prioritize building a brick home over more expressive reasons for joining the organization such as unity, community building/mobilization, or leadership development will be affiliated with these religious traditions (Hypothesis 4). And the final two hypotheses suggest that women who tend to more highly prioritize community-mindedness over more expressive and/or practical reasons are expected to be attracted to churches with a similar history such as mainline churches (Buys \& Nambala, 2003; Cowser, 2013). Narratives of Federasi voices will augment these quantitative results.

\subsection{Examining Religious Affiliation among Federasi: Namibian Demographics}

This mixed-methodological study examines whether ethnicity and Federation-related dynamics influence religious affiliation as well as respondents' corresponding experiences. The following sections include: demographics on Namibia; data collection processes; and, analytical approaches used. First, located near the southwestern tip of Africa, Namibia has a population of about 2.3 million residents. Approximately two-thirds of Namibians live in rural areas. The population consists of blacks $(87.5 \%)$, coloreds $(6.5 \%)$, and whites $(6 \%)$. The most common tribes are; Ovambo (50\%), Kavango (9\%), Herero (7\%), and Damara $(7 \%)$. Although English is the official language, Afrikaans is the lingua franca. Namibia's economy is driven by mining, fishing, and commercial agriculture. Moreover, although the country is reportedly one of the richest in sub-Saharan Africa, a small wealthy white cadre of the population control its markedly unequal income distribution. Unemployment rates range from $40 \%-70 \%$, depending upon the region of the country. For example, Namibia is reported to have one of the highest per capita incomes in sub-Saharan Africa. Yet a disproportionate percentage of its black residents are poor. In addition, Namibia's white minority and its' 
merging black elite have average per capita incomes of about $\mathrm{N} \$ 100,000$ annually; blue-collar black workers average $\mathrm{N} \$ 4,500$ annually. And the majority of Federasi average only N\$500 yearly (about \$35 U.S. dollars) (UNDP, 2015).

Given our study focus, it is important to consider religious ties. Over $90 \%$ of respondents are attendees or members of churches. Forty-nine percent of Federasi are members of mainline churches; among that group, almost $70 \%$ are members of either the Evangelical Lutheran Church in the Republic of Namibia (ELCRN) or the Evangelical Church in Namibia (ELCN). These two mainline churches have adherents in all thirteen Namibian regions and heavy concentration of members among Ovambo and Kavango women in the Ovamboland and Kavangoland areas of north, north-central, and central Namibia. African Methodist Episcopal (AME) churches are concentrated largely among the Nama and Nama-Damara-groups of southern Namibia. Twenty-three percent of Federasi attend Pentecostal or non-denominational churches; $19 \%$ are Roman Catholic. The most common Mainline churches represented in this study include; Lutheran, African Methodist Episcopal, Anglican, Dutch Reform, Baptist, and Methodist. The most common Pentecostal, Apostolic, and Gospel churches include; Born Again Church, New Apostolic, Apostolic Faith Mission, God Leads Us, Old Apostolic, and Vineyard Church. Ethnicity is defined here based on residence, language, and other distinct cultural factors (summarized in Table 1). We consider some of the factors that may shape these religious ties.

Table 1. Summary of Namibian Ethnic Groups in the Study

\begin{tabular}{|c|c|c|c|c|}
\hline \multicolumn{5}{|c|}{ Ethnic Group is defined based on language, place of residence, and cultural customs } \\
\hline Ethnic Group & Regions & $\begin{array}{l}\text { Percent of } \\
\text { Population }\end{array}$ & $\begin{array}{l}\text { Poverty Rate in } \\
\text { Region }\end{array}$ & Thumbnail Description \\
\hline A. Coloreds & Hardap & $3.5 \%$ & $17.2 \%$ & $\begin{array}{l}\text { urban dwellers: often elites: more working } \\
\text { poor: often somewhat more educated: } \\
\text { Rehoboth Basters: speak Afrikaans as their } \\
\text { first language }\end{array}$ \\
\hline B. Damara & Erongo & $7.0-8.5 \%$ & $6.3 \%$ & $\begin{array}{l}\text { farmers: Erongo region: speak Khoekhoe: live } \\
\text { in Damaraland }\end{array}$ \\
\hline $\begin{array}{l}\text { C. Nama, } \\
\text { Nama-Damara }\end{array}$ & Karas & $11.3 \%$ & $14.5 \%$ & $\begin{array}{l}\text { pastoralists: hunter- gatherers: speak Khoikhoi: } \\
\text { Namaqualand }\end{array}$ \\
\hline D. Oshiwambo & Omusati & $48.9 \%$ & $28.6 \%$ & 9 tribes: about 700,000 members: northern \\
\hline & Ohangwena & & $35.3 \%$ & Namibia: agriculturalists, hunting, fishing: \\
\hline & Oshana & & $21.1 \%$ & multiple dialects \\
\hline & Oshikoto & & $42.6 \%$ & \\
\hline & Otjozondjupa & & $27.5 \%$ & \\
\hline E. Otjiherero & $\begin{array}{l}\text { Kunene } \\
\text { Omaheke }\end{array}$ & $8.6 \%$ & $\begin{array}{l}38.9 \% \\
26.2 \%\end{array}$ & $\begin{array}{l}4 \text { major groups: about } 15,000 \text { nomadic } \\
\text { pastoralists: Gobabis region near Kalahari } \\
\text { Desert }\end{array}$ \\
\hline
\end{tabular}

Key: The male/female Namibian population percentages are about 50\% male $(1,117,420)$ and $50 \%$ female $(1,094,887)$ [Sources: CIA World Factbook 2015 and National Planning Commission, Poverty and Deprivation in Namibia Report 2015]. 


\subsection{Data Collection and Analytical Plan}

This study is based on interview and survey data collected January 20, 2010 - July 7, 2010. (note 9) Participants were located using a snowball sampling method with the assistance of key informants. A 22-question survey was used to query Federasi about the organization, its objectives, accomplishments, and challenges, as well as their experiences. Questionnaire completion times averaged about 35 minutes. A second 10-question survey was also used to interview 6 key Federasi leaders and 3 senior government officials (instruments provided upon request). These latter participants were selected because of their high-level of Federation involvement and extensive knowledge about the group; these interviews were audio-taped and lasted about one hour. (note 10) Afrikaans, English, Ovambo, Herero, Caprivian, Tswana, Damara, Nama, and Kavango languages were spoken during field work. To ensure accurate data collection and cultural sensitivity, translators were present in each of the 30 towns and villages visited as well as during meetings. The majority of Federasi could speak and write in English; 80\% of questionnaires were completed without the aid of a translator (pseudonyms are used). (note 11)

\subsection{Quantitative Analyses: Dependent and Independent Variables}

Religious involvement is captured using the dependent variable, Religious Affiliation, "What other organizations are you involved in? What is the name of your church?" Listed churches were aggregated into the following three categories: Mainline; Gospel, Pentecostal, or Apostolic; and, Roman Catholic. (note 12) We acknowledge that the dependent variable does not capture the quality or nature of these religious ties. Women's religious involvement may vary. Moreover, some mainline churches may include worship dimensions similar to those found in some Pentecostal congregations and vice versa. And as noted in the literature review, broad differences are apparent in these three faith traditions. Despite these constraints, the variable provides a straightforward way to capture religious affiliation and will be augmented by our qualitative results. Nine independent variables are tested. First, bivariate statistics for the study variables are reported based on the three religion categories (Table 2). Chi-square or t-tests are used to identify statistically significant differences based on the study variables. Figures 1 and 2 present the most common reasons for Federasi involvement by ethnicity and religious affiliation, respectively.

Modeling is performed during the third analysis phase. Because the dependent variable, Religious Affiliation, reflects three distinct nominal groups that are assumed to be unordered, we use multinomial logit modeling (i.e., whether or not respondents are affiliated with Mainline; Gospel, Pentecostal, or Apostolic; or Roman Catholic traditions) (Long \& Freese, 2001). The four ethnic groups considered are Nama-Damara, Oshiwambo, Otjiherero, and Colored (Rehoboth Basters). The "Other" reference group primarily includes RuKwangali and Eastern Caprivians. (note 13) In each step, the dependent variable is regressed on: four 0-1 variables that identify ethnic groups (Model 1); ethnicity and two controls, Post-Bantu education and Federation tenure (Model 2); and, all nine indicators together, including three variables that gauge Federasi views and behaviors about the organization (Model 3). Modeling results are provided in Table 3. Operationalizations and survey questions are 
provided in the appendix. Bivariate correlations are available upon request.

\subsection{Qualitative Analysis}

The quantitative analyses assess Federasi religious affiliations; qualitative findings help illumine how religion may be related to Federation involvement. Content analysis is used to uncover emergent themes and analyze the narratives of the Federasi to "identify and explain the ways people use or operate in a particular setting and how they come to understand things, account for, take action, and generally manage their day-to-day life" (Berg, 2009: 340). Interviews and survey responses are analyzed to determine meanings in the data as well as uncover representative patterns (Krippendorf, 1980). A close reading of the data enabled us to identify: how Federasi describe their experiences in general; how their lives have been influenced by religion; and, whether their views are informed by existing literature on religion among this group (Krippendorf, 1980).

\section{Findings}

4.1 Bivariate Results of Religious Affiliation

Table 2. Bivariate Results for Federation Sample by Religious Affiliation

\begin{tabular}{lccccc}
\hline \multicolumn{1}{c}{ Study Variables } & Sample & Mainline & $\begin{array}{c}\text { Gospel- } \\
\text { Pentecostal }\end{array}$ & Catholic & $\mathrm{t} / \mathrm{X} 2$ \\
\hline $\begin{array}{l}\text { Ethnicity } \\
\text { \% Nama-Damara }\end{array}$ & 50.8 & 44.1 & 62.7 & 55.6 & $X^{2}=6.41^{*}$ \\
\% Oshiwambo & 16.3 & 24.8 & 5.1 & 5.6 & $X^{2}=17.76^{* * *}$ \\
\% Otjiherero & 12.8 & 13.1 & 10.2 & 14.8 & $X^{2}=0.57$ \\
\% Colored & 8.9 & 4.8 & 10.2 & 18.5 & $X^{2}=9.23^{* *}$ \\
\% Other & 11.2 & 13.1 & 11.9 & 5.6 & $X^{2}=1.88$ \\
$\begin{array}{l}\text { Controls } \\
\text { \% Post-Bantu Education }\end{array}$ & 19.2 & 29.0 & 11.9 & 22.3 & $X^{2}=6.87^{*}$ \\
$\begin{array}{l}\text { Years in Federation (s. d.) } \\
\text { Reasons for Joining the Federation }\end{array}$ & $6.7(5.1)$ & $6.2(4.9)$ & $6.4(4.5)$ & $8.35(5.9)$ & $\mathrm{t}=\mathrm{ns}^{+}$ \\
\% Build Brick House & & & & & \\
\% Community Building & 85.1 & 79.3 & 91.5 & 90.7 & $X^{2}=6.81^{*}$ \\
$\begin{array}{l}\text { Federation Meaning } \\
\text { \% Unity for the Poor }\end{array}$ & 61.9 & 57.9 & 69.5 & 81.5 & $X^{2}=10.20^{* *}$ \\
$\mathrm{n}$ & 23.8 & 29.4 & 28.6 & 28.9 & $X^{2}=0.01$ \\
\hline
\end{tabular}

Key: Federation 2010 data: $\mathrm{N}=258$. Column percents are provided. t-test and $X^{2}$ significance at $* * * p<.001, * * p<.01, * p<.05 . n s=$ insignificant. + means tests for all combinations were insignificant. Post-Bantu education is equivalent to 8 th-12th grades. 


\section{Mll Macrothink}

Bivariate results provided in Table 2 show that $50.8 \%, 16.3 \%, 12.8 \%$, and $8.9 \%$ of Federasi here are Nama-Damara, Oshiwambo, Otjiherero, and Colored, respectively. Differences in religious affiliation are evident and statistically significant for six of the nine indicators. For example, a greater relative percentage of women affiliated with Gospel, Pentecostal, or Apostolic churches are Nama-Damara (62.7\%), followed by Catholic and Mainline. And about $25 \%$ of women affiliated with mainline churches are Oshiwambo; similar percentages of Otjiherero women attend one of the three church groups. After Nama-Damara, Federasi who are Catholic are slightly more apt to be colored. When education is considered, Federasi who are affiliated with mainline churches can be described as Post-Bantu educated (29.0\%). Religious ties do not appear to vary based on Federation tenure. Yet a greater relative percentage of women affiliated with Gospel, Pentecostal, or Apostolic (91.5\%) site that building a brick home was the first reason they joined the Federation; then, Catholics followed by mainline women prioritized this reason first. However, Federasi affiliated with the Catholic tradition (81.5\%) tended to prioritize community building as central for joining the organization. However, affiliation differences are not apparent for Federasi who associate the organization with unity among the poor.

Several patterns in Figures 1 and 2 show the top reasons why Federasi remain in the organization by ethnicity and religious ties, respectively, and inform readers about how respondents view themselves, each other, and their communities. Figure 1 shows that, regardless of ethnicity, women tend to prioritize the Federation as an organization designed to empower the poor and build community above its other possible benefits. Yet women who are Nama-Damara, Oshiwambo, and Otjiherero rank this benefit higher than their peers. More practical reasons such as home ownership, locating land, and other forms of economic security tend to be ranked second. Yet Coloreds tend to prioritize such economic benefits more highly than do their counterparts. Self-development and personal socio-psychological benefits tend to be ranked a distant third. When religious ties are considered in Figure 2, Federasi affiliated with Mainline and Gospel, Pentecostal, or Apostolic churches tend to remain in the organization because of its mobilizing efforts for the poor. Roman Catholics prioritize home ownership and other economic benefits more highly, but rank mobilization second. Individual-level socio-psychological benefits are ranked third in each faith tradition. But will differences in Federasi profiles influence religious affiliation when the variables are examined simultaneously? 


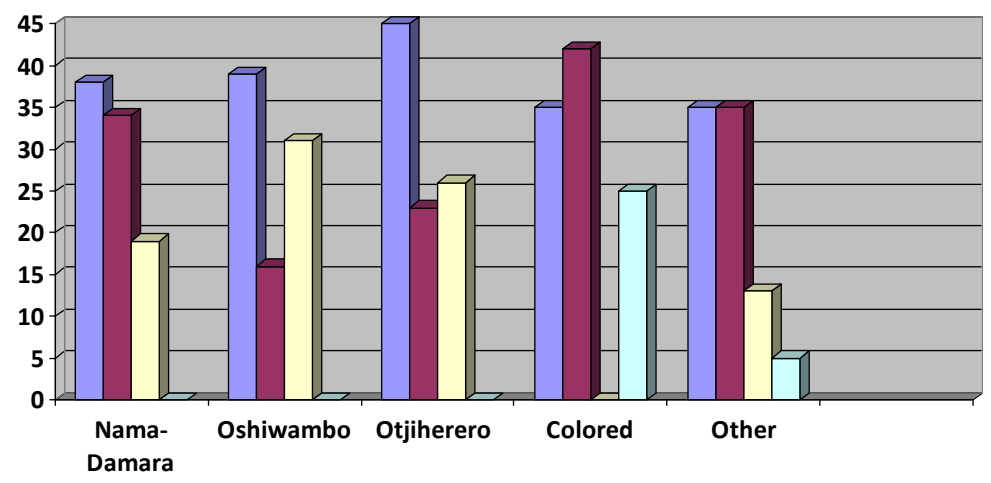

Figure 1. Four Most-Cited Reasons Respondents Remain in the Federation by Ethnicity

Key: Federation 2010 data: $\mathrm{N}=258$. Based on the question, "What does the Federation mean to you?" Up to four answers, including 'no response' were possible (each n represents response frequency). Self-Dev. means self-development. Nama-Damara =Damara, Nama, and Nama-Damara. Nama-Damara $=131$, Oshiwambo $=42$, Otjherero $=33$, Colored $=23$, Other $=29$.
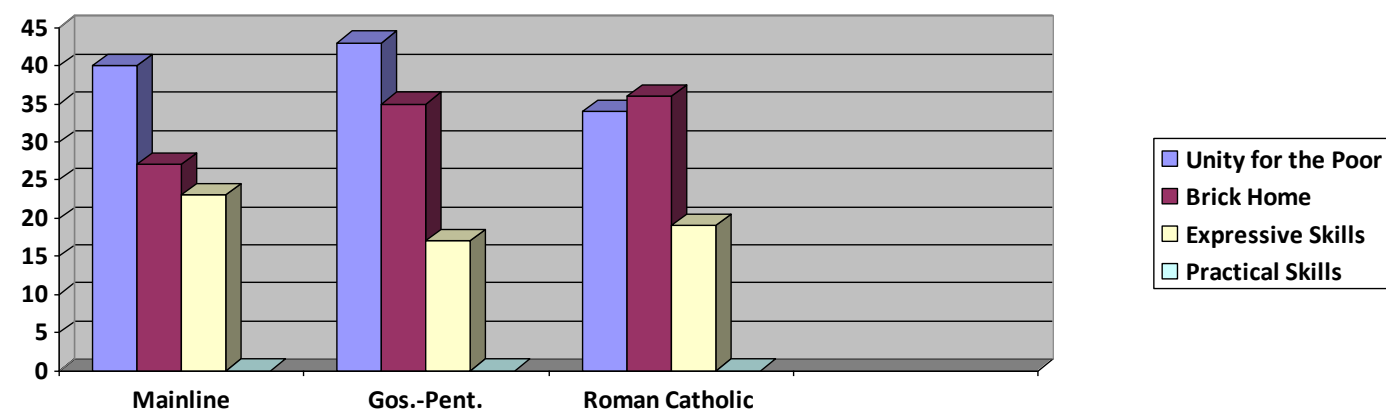

Figure 2. Four Most-Cited Reasons Respondents Remain in the Federation by Religion

Key: Federation 2010 data: $\mathrm{N}=258$. Based on the question, "What does the Federation mean to you (now)?" Up to four answers, including 'no response' were possible (each $\mathrm{n}$ represents response frequency). Gos.-Pent. = Gospel, Pentecostal, and Apostolic. Expressive skills include abilities such as leadership and listening. Practical skills include abilities such as administrative and problem-solving skills. Mainline = 145, Gos. - Pent (Gospel, Pentecostal, and Apostolic) $=59$, and Roman Catholic $=54$.

\subsection{Modeling Federasi Religious Affiliation}

The models presented in Table 3 examine the combined effects of ethnicity, demographics, and experiential indicators on religious affiliation among the Federasi. Model 1 (Panel A) only focuses on the four ethnicity variables; several help explain religious ties (Pseudo $R^{2}=$ 0.11). Although Federasi who are identified as Nama-Damara, Otijherero, or Colored are no more apt to be affiliated with Pentecostal/Gospel/Apostolic traditions than mainline churches 
than their counterparts from other ethnic groups, the odds of being Pentecostal relative to being Mainline are 0.23 times less for Federasi identified as Oshiwambo than for other ethnic groups. Moreover, when ethnic differences between Roman Catholic and Mainline ties are assessed, our results show no statistically significant differences between such affiliations for Oshiwambo and Otijherero Federasi. However, the odds of being Catholic as compared to Mainline is 9.05 times greater for Coloreds than for "Other" ethnic groups (Model 1, Panel B). Albeit minimal, the odds of being Catholic as compared to Mainline is about 3 times greater for Nama-Damara (odds $=2.97, \mathrm{p}<.10$ ) than for Other ethnic groups. Additionally, Coloreds are about four times more apt to be Catholic than Pentecostal (Model 1, Panel C).

The possible effects of several demographic variables are considered in Model 2 (Pseudo $R^{2}$ $=0.15$ ). Several ethnicity indicators continue to be important. First, after controlling for education and Federation tenure, the odds of being Pentecostal rather than Mainline are still less (odds $=0.19$ ) for Oshiwambo than for other ethnic groups (Model 2, Panel A). Moreover, increased education, Post-Bantu here, decreases odds of Pentecostal over Mainline ties. Next, the odds of being Catholic (Model 2, Panel B) as compared to Mainline continue to be notably higher for Coloreds than for Other ethnic groups (odds $=8.05$ ). And time in the Federation (odds $=1.07$ ) tends to positively influence Catholic ties over Mainline ones. When Catholic and Pentecostal comparisons are made (Model 2, Panel C), results show a minimal, positive relationship between having Catholic affiliations rather than Pentecostal ties for Federasi identified as Otijherero (odds $=4.74, \mathrm{p}<.10$ ) or Colored (odds $=4.59, \mathrm{p}<.10$ ) as compared to their peers in other ethnic groups. Moreover, the odds of being Catholic rather than Pentecostal are 3.33 times and 1.10 times greater for better educated Federasi and women with longer organizational stints, respectively, as compared to their counterparts.

The final model considers the effects of women's views about the Federation, including some of their reasons for involvement. Inclusion of these three additional indicators is important and increases the model's predictive ability over the baseline test two-fold (Model 3, Pseudo $\left.R^{2}=0.24\right)$. Several patterns continue and show that, after controlling for education, Federation tenure, and Federasi attitudes and decisions about the organization in Panel A, the odds of being Pentecostal rather than mainline are not significantly different for the ethnic groups under study. Yet Federasi with more formal education have lower odds of having Pentecostal ties rather than mainline affiliations. Next, sentiments about the Federation are important in gauging religious affiliations. For example, the odds of being Pentecostal rather than affiliated with a Mainline tradition are 7.42 times greater for Federasi who joined the organization specifically to build a brick house rather than for more expressive reasons. When we compare Catholic versus Mainline affiliations (Model 3, Panel B), the odds of being part of the former rather than the latter religious tradition continue to be substantial and 11.30 times greater for Coloreds and 4.46 times greater for Otijherero than for other ethnic groups, respectively. Longer organization tenure continues to positively influence Catholic over Mainline religious ties (odds $=1.11$ ). Furthermore, two of the three new indicators are predictive and suggest that the odds of being Roman Catholic rather than mainline are 3.06 times greater for Federasi who joined the organization to building community as compared to their peers who joined for either more economic, practical or individual reasons. Similarly, 
associating the Federation with its ability to unify the poor has over a two-fold influence on being Catholic rather than mainline.

Table 3. Multinomial Logit Models for Religious Affiliation for Federation Sample

\begin{tabular}{|c|c|c|c|}
\hline & $\begin{array}{l}\text { Model } 1 \\
\text { Ethnicity }\end{array}$ & $\begin{array}{l}\text { Model } 2 \\
\text { Ethnicity \& Controls }\end{array}$ & $\begin{array}{c}\text { Model } 3 \\
\text { All Variables }\end{array}$ \\
\hline \multicolumn{4}{|c|}{ Panel A: Pentecostal, Apostolic, and Gospel compared to Mainline } \\
\hline \multicolumn{4}{|l|}{ Ethnicity } \\
\hline Nama-Damara (1=yes) & $0.45(1.57)$ & $0.23(1.26$ & $0.64(1.90)$ \\
\hline Oshiwambo (1=yes) & $-1.49(0.23)^{*}$ & $-1.65(0.19)^{*}$ & $-1.34(0.26)$ \\
\hline Otjiherero (1=yes) & $-0.15(0.86)$ & $-0.40(0.67)$ & $0.37(1.45)$ \\
\hline Coloreds $(1=$ yes $)$ & $0.84(2.33)$ & $0.56(1.76)$ & $0.25(1.29)$ \\
\hline \multicolumn{4}{|l|}{ Controls } \\
\hline Post-Bantu Education (1=yes) & & $-1.04(0.35)^{*}$ & $-1.58(0.21)^{* *}$ \\
\hline Years in Federation $(1-15+)$ & & $-0.23(0.97)$ & $-0.05(0.95)$ \\
\hline \multicolumn{4}{|l|}{ Reasons: Joining the Federation } \\
\hline Build a Brick House (1=yes) & & & $2.01(7.42)^{*}$ \\
\hline Community Building (1=yes) & & & $-0.13(0.88)$ \\
\hline \multicolumn{4}{|l|}{ Federation Meaning } \\
\hline Unity for the Poor (1=yes) & & & $0.25(1.29)$ \\
\hline \multicolumn{4}{|c|}{ Panel B: Roman Catholic compared to Mainline } \\
\hline \multicolumn{4}{|l|}{ Ethnicity } \\
\hline Nama-Damara (1=yes) & $1.09(2.97)^{+}$ & $1.01(2.73)$ & $0.82(2.26)$ \\
\hline Oshiwambo (1=yes) & $-0.64(0.53)$ & $-0.61(0.55)$ & $-0.20(0.82)$ \\
\hline Otjiherero (1=yes) & $0.98(2.67)$ & $1.16(3.18)$ & $1.49(4.46)^{+}$ \\
\hline Coloreds (1=yes) & $2.20(9.05)^{* *}$ & $2.09(8.05)^{* *}$ & $2.42(11.30)^{* *}$ \\
\hline \multicolumn{4}{|l|}{ Controls } \\
\hline Post-Bantu Education (1=yes) & & $0.16(1.18)$ & $0.03(1.03)$ \\
\hline Years in Federation $(1-15+)$ & & $0.07(1.07)^{*}$ & $0.11(1.11)^{* *}$ \\
\hline \multicolumn{4}{|l|}{ Reasons: Joining the Federation } \\
\hline Build a Brick House (1=yes) & & & $0.08(1.08)$ \\
\hline Community Building (1=yes) & & & $1.12(3.06)^{*}$ \\
\hline \multicolumn{4}{|l|}{ Federation Meaning } \\
\hline Unity for the Poor (1=yes) & & & $0.81(2.25)^{+}$ \\
\hline \multicolumn{4}{|c|}{ Panel C: Roman Catholic compared to Pentecostal, Apostolic, and Gospel } \\
\hline \multicolumn{4}{|l|}{ Ethnicity } \\
\hline Nama-Damara (1=yes) & $0.64(1.89)$ & $0.77(2.17)$ & $0.18(1.19)$ \\
\hline Oshiwambo (1=yes) & $0.85(2.33)$ & $1.05(2.85)$ & $1.15(3.15)$ \\
\hline Otjiherero (1=yes) & $1.14(3.11)$ & $1.56(4.74)^{+}$ & $1.13(3.08)$ \\
\hline Coloreds (1=yes) & $1.36(3.89)^{+}$ & $1.52(4.59)^{+}$ & $2.17(8.78)^{+}$ \\
\hline \multicolumn{4}{|l|}{ Controls } \\
\hline Post-Bantu Education (1=yes) & & $1.20(3.33)^{*}$ & $1.61(4.99)^{*}$ \\
\hline Years in Federation $(1-15+)$ & & $0.10(1.10)^{*}$ & $0.16(1.18)^{* * *}$ \\
\hline \multicolumn{4}{|l|}{ Reasons: Joining the Federation } \\
\hline Build a Brick House (1=yes) & & & $-1.93(0.15)^{*}$ \\
\hline Community Building ( $1=$ yes $)$ & & & $1.25(3.47)^{*}$ \\
\hline \multicolumn{4}{|l|}{ Federation Meaning } \\
\hline Unity for the Poor (1=yes) & & & $0.56(1.75)$ \\
\hline $\mathrm{R} 2$ & 0.11 & 0.15 & 0.24 \\
\hline $\mathrm{N}$ & 258 & 258 & 258 \\
\hline
\end{tabular}

Key: Federation 2010 data: $\mathrm{N}=258$. Coefficients presented first: odds are provided in parentheses. ${ }^{* * *} \mathrm{p}<.001$, ${ }^{* *} \mathrm{p}<.01,{ }^{*} \mathrm{p}<.05,+\mathrm{p}<.10$. 
Lastly, five indicators help explain differences in Roman Catholic and Pentecostal affiliations (Model 3, Panel C). First, the odds of being Catholic rather than Pentecostal continue to be somewhat greater for Coloreds (odds $=8.78, \mathrm{p}<.10$ ) as compared to their peers in other ethnic groups; differences for Otijherero are no longer apparent. Moreover, the odds of being Catholic rather than Pentecostal are 4.99 times and 1.18 times greater for better educated Federasi and women with longer organizational tenure, respectively, as compared to their counterparts. And two of the three attitudinal variables are important here. The odds of being Catholic relative to being Pentecostal are 0.15 times less for Federasi who joined the organization specifically to build brick homes than for women who joined for other reasons. Yet odds are greater (odds $=3.47, \mathrm{p}<.05$ ) that Federasi who joined the organization to build community rather than for more practical or personal reasons are Catholic than Pentecostal. Representative quotes in the subsequent section help further explain Federasi's religious affiliations.

\subsection{Federasi Narratives on Religion}

The modeling results empirically inform our understanding about religious and Federation ties. Yet they do not capture some of the nuances among Federasi voices. Narratives extend our quantitative findings and suggest several emergent themes that correlate respondents' views about God, the Federation, and their community. Moreover, we contend that these narratives support the role of the Federation as a proxy church for many of its members. The first theme illumines religious symbolism used by Federasi; the second theme provides examples of servanthood among women to augment the limited local congregational support for the poor. These results suggest some of the ways tangible and intangible dynamics often associated with churches are apparent as Federasi discuss organizational ties, community engagement, and personal agency. Representative quotes and thematic analyses follow.

Theme 1: The Federation as a Proxy-Church - Symbolism

This theme emphasizes symbolism and rituals typically associated with religious and/or congregational life. Remarks suggest that Federasi have church ties or have participated in the past such that these concepts and activities are familiar. For example, Nandi, a 40-year-old food seller from Gobabis, Omaheke, succinctly describes the key dimensions of a Federation meeting, "we come together and discuss, pray, and solve problems." In addition to referencing the mobilizing, communication, and problem-solving dimensions of the organization, Nandi includes a religious/spiritual ritual historically associated with churches, in general, and with black churches in particular as a precursor to community action (Barnes, 2005a; Lincoln \& Mamiya, 1990; Pattillo-McCoy, 1998). For Laina, a 49-year-old domestic worker from Keetmanshoop, Federation involvement can foster love of self and others that manifests in expressive (i.e., increased loved) and instrumental (i.e., working together to build houses) outcomes:

To love people and work together...it makes a difference in my life and also in other people's lives...As a member, I feel proud and want to see my community working together to love each other. 
For Laina, the Federation is a safe space of unconditional love and acceptance in an often unfriendly world. Literature suggests that for many blacks, churches have provided similar benefits (Barnes, 2005; Cowser, 2013; Lincoln \& Mamiya, 1990). The above wording provides strong evidence of the para-religious leanings of the organization as well as how some members' religious and para-religious affiliations can inform each other.

Similarly, the following view expressed by the next Federasi suggests a direct connection between, God, the Federation, and her local community:

[The Federation] means to improve poor people in living conditions...Community members need to know their rights and to follow the will of the Almighty God so that they can do things in the right way. (Mona, a 38-year-old bookkeeper and office administrator from Ongwediva)

Although she has already built her own brick home, Mona recognizes the importance of continued Federation involvement. Her community-focused perspective links its spiritual impetus to political outcomes. In addition, she suggests that intangible factors such as belief in God can engender more practical behavior among members. In this way, for such women, the Federation has become a bridge between both spiritual and secular dimensions as well as between God and humanity (Cowser, 2013; Totemeyer, 2010). Finally, Sonya, a 42-year-old domestic worker from Nalitungwe, Chomos, describes another expressive benefit of Federation participation; "I feel good because women can be head of the house, be a leader, pastor." In addition to building her brick house, Sonya's remark points to the ability of the organization to center the lives, needs, and concerns of marginalized women to empower them as leaders in their homes and to even aspire to ecclesiastical positions. Moreover, her focused remark provides a direct counter-narrative to the sexism, racism, and classism most Federasi experience (Buys \& Nambala, 2003; Collins, 1998, 2000; Loubser, 1987; Totemeyer, 2010).

\section{Theme 2: The Federation as a Proxy-Church - Service}

The second theme complements the first and suggests that, although most Federasi are involved in local churches, these collectives are inadequate to meet their varied needs. Women in this category specifically describe activities in which they engage that have historically been under the purview of churches. In addition, comments confirm the mounting challenges associated with arresting chronic poverty than make MBOPs like the Federation a necessity (Chen et al, 2007; Cowser \& Barnes, 2016; Hishongwa, 1983).

According to Cara, a forty-five-year-old wife and mother of four, Federation involvement has enabled her to develop leadership traits that translate into community activism; "that's what I do...leadership means standing up for my community...We go to the jail and give them toiletries and we pray for them." Cara's para-religious participation is an extension of her religious involvement in a local mainline church. In addition to describing linkages between micro-level (i.e., volunteerism at local jails) and macro-level efforts (i.e., community uplift), her comment reflects that of a servant leader where the Federation and her church are conduits for her attitudes and actions (Ngunjiri, 2010). Moreover, Cara's comment alludes to 
the reality that the Federation augments the limited governmental and social services in Namibia (Chen et al, 2007; Tripp et al, 2009; Tvedten, 2011). A local leader describes the limited services most churches offer the poor:

The people are just going to church on Sunday morning and go(ing) home and that's it. We have AIDS in our country and some churches like the Catholic and...AME churches have programs...but still the impact that this program makes especially on the poor is just very, very low. (Rev. Sanna Long from Ongwediva)

The above Federasi is referring to 2012 figures that report an estimated 120,000 female ages 15 years or older and 18,000 children living with HIV/AIDS in Namibia (www.cdc.gov/globalaids). In addition, 2013 statistics suggest: 14.3\% of Namibians ages 15-49 years old have contracted HIV; 6,600 AIDS deaths; and, 96,000 orphans due to the disease (HIV-AIDS-at-CDC/countries/Namibia/). Although several denominations have responded to the pandemic, they are in the minority and their impact is limited. Most often, churches provide soup and some assistance with funerals. Because the poor must fend for themselves, the Federation serves as a bridging institution between churches and the government in response to poverty. Similarly, black churches have a long history of providing social services to congregants and community members and filling the gap between government-based support (Barnes, 2005a; Lincoln \& Mamiya, 1990). According to respondents, the Federation has embraced that role in Namibia.

The next respondent describes a servant model that fosters the requisite sweat equity needed to accomplish Federation goals:

The courageous thing for me was growing up in a rural area where there was no life...it [the Federation] means a lot for me because it has improved my life and now I built my own house and [am] independent and will not wait for someone or the government to improve my life...I want to see the Federation grow and work together to help the local government to reach the vision. (Lida, 56-year-old seamstress from Omatupe, Otiozondijupa)

In addition to detailing a painstaking building process, Lida acknowledges how her quality of life has been enhanced and her sense of agency. Her remark also alludes to the attenuated government aid that exists and hope for strategic alliances between the MBOP and the government. Moreover, similar to the practical knowledge and skills often provided in black churches (Barnes, 2005a; Lincoln \& Mamiya, 1990), her insight illustrates some of the tangential benefits of Federation involvement that inform and empower poor women to realize what is possible via mobilization and what could be possible via strategic organizational alliances between entities such as the Federation, the government, and local churches (Afkhami et al, 2001; Bystydzienski \& Sekhon, 1999; Falola \& Teboh, 2013; Hishongwa, 1983). The final observation by Meena, a 36-year-old pensioner from Kamanjab, Kunene, substantiates Federation benefits and continued problems; "Beyond housing there are still needs like clinics, shops, churches, police stations, playgrounds, public toilets, electricity, and water." Although appreciative of the inroads made by the MBOP, Meena's list of absent, but needed resources and institutions, includes churches, suggesting that these 
religious organizations are not effectively involved in local community improvements (Chen et al, 2007; Christens, 2010).

\section{Discussion}

Several important patterns emerge when we revisit our hypotheses that illustrate the influence of ethnicity on religious ties. First, regardless of ethnicity, more formal education (i.e., Post-Bantu level training) is positively related to Roman Catholic affiliations, but negatively so for Pentecostal, Apostolic, or Gospel ties. Moreover, regardless of the other indicators, Federasi with longer stints in the organization are more likely to be Roman Catholic than Mainline or Roman Catholic than Pentecostal, Apostolic, or Gospel. Next, our findings do not support the first hypothesis; in actuality Nama-Damara are somewhat more likely to be Roman Catholic than Mainline (in Model 1, Panel B), but no more or less likely to be associated with the other two religious groups. There is minimal support for Hypothesis 2 . Although mainline ties more than Pentecostal, Apostolic, or Gospel ones are apparent for Oshiwambo in several tests, Otjiherero are somewhat more apt to be Roman Catholic than either of the remaining two religious traditions (Model 2, Panel C and Model 3, Panel B). However, there is consistent support for Hypothesis 3; even after considering controls, women who are Coloreds are more likely to be affiliated with the Roman Catholic tradition than women from other ethnic groups (Models 1-3, Panels B and C). The fourth hypothesis is largely affirmed; women who join the Federation specifically to build a brick house tend to be affiliated with Pentecostal, Apostolic, or Gospel traditions than Mainline or Catholic faiths as compared to women who join for other reasons (Mode1 3, Panels A and C). Yet, Hypothesis 5 is not supported. Federasi who prioritize community building for the poor over other reasons for joining the organization are actually more likely to be affiliated with Roman Catholicism rather than Mainline religious traditions (or Pentecostal, Apostolic, or Gospel) (Model 3, Panels B and C). Lastly, minimal support is evident for Hypothesis 6. Results from Model 3 show that, women who primarily consider the Federation an organization to unify and mobilize the poor are actually more likely to be affiliated with Catholicism rather than Mainline groups (Panel B) as compared to women who associate the organization with more individual-level outcomes. Additionally, results from the narrative analysis illustrate ways the Federation, as a para-religious organization, provides tangible and intangible benefits, many of which have been associated with historic black churches, but are not provided by most local congregations (Barnes, 2005a; Chen et al, 2007; Christens, 2010; Cowser \& Barnes, 2016; Iipinge \& Lebeau, 2005; Iken, 1993; Lincoln \& Mamiya, 1990).

\section{Conclusion}

This study examines dimensions of religious and para-religious life for a cadre of Namibian women who, despite chronic poverty, are attempting to forge a better life for themselves, their families, and their communities. Our empirical results suggest correlates between ethnicity, religious affiliation, and Federation participation; Federasi narratives further 
support these results (Buys \& Nambala, 2003; Cowser, 2013; Totemeyer, 2010). Findings show the influence of ethnicity on religious ties for Coloreds, specifically, and less so for Nama-Damara, Oshiwambo, and Otijherero, and as well as the relatively consistent effects of education and Federation tenure. Given the exploratory aspects of our ethnicity tests, additional studies are needed (Cowser \& Barnes, 2016; Hishongwa, 1983; Iipinge \& Lebeau, 2005; Iken, 1993). Findings also show consistent, direct ties to Catholicism for Federasi who can be broadly considered "working poor" (i.e., women who tend to have more formal education, speak Afrikaans, have longer Federation tenure, and tend to associate the Federation with mobilization). In contrast, their peers who tend to be relatively more impoverished tend to prioritize the economic benefits of Federation involvement more highly and tend to be affiliated with Pentecostal, Apostolic, or Gospel churches. We consider these latter two findings some of the most important results of the analysis that warrant further research.

Ninety percent of Federasi are affiliated with a local church. Yet such churches do not appear to be responding to the myriad economic and non-economic problems Federasi and their families and communities face. Based on our results, a strong argument can be made that the Shack Dwellers Federation of Namibia is a proxy-church for many of its members. Although ethnicity was correlated with certain religious ties, regardless of ethnicity, respondents participate in the Federation. And their involvement in this collective appears to provide expressive and instrumental benefits that parallel many of the outcomes experiences by blacks historically as a result of congregational participation (Barnes, 2005a; Lincoln \& Mamiya, 1990; Pattillo-McCoy, 1998). Furthermore, the symbolism used and practices in which they engage suggest both church exposure and that the Federation mimics key features commonly associated with churches to extend social services not provided by the government or local congregations. Our results should not be considered an indictment of Namibian churches, but rather an assessment of some of the personal and organizational decisions poor Namibian women have made as a result of the sobering conditions they face and limited religious and governmental resources at their disposal. These results also suggest the need to investigate: non-traditional ways in which the Federation responds to the separation of Church and State; cross-gender mobilizing efforts; and, non-traditional best practices to address systemic problems. Additional mixed-methodological studies will help provide a more comprehensive assessment of this complex collective and its indomitable members.

Our findings do not do justice to the lives and experiences of Federasi as they engage religious and para-religious spaces. However, we have endeavored to provide a glimpse of their trials and triumphs. Long-term, their goal is to collectively eliminate poverty in Namibia, short-term, to escape life in shantytowns. And most Federasi seem to realize that these two objectives are not mutually exclusive. Moreover, they acknowledge the varied beneficence of the MBOP. A strong case can be made for an indelible link between God, the Federation, and the community for Federasi here. However, members also believe that, for their community mobilization efforts to more effectively turn the tide toward equality and social justice, both the local government and local churches must become more concertedly involved. 


\section{References}

Afkhami, M., Eisenberg, A., \& Vaziri, H. (2001). Leading to Choices: A Leadership Training Handbook for Women. Bethesda, MD: Women's Learning Partnership for Rights, Development, and Peace.

Abdela, L. (2004). From palm tree to parliament: Training women for political leadership and public life. Gender, Development, and Citizenship, 16-18, edited by C. Sweetman. London: Oxfam.

Barnes, S. (2005). The cost of being poor: A comparative study of life in poor urban Neighborhoods in Gary, Indiana. New York: State University Press of New York.

Barnes, S. (2005a). Black church culture and community action. Social Forces, 84(2), 967-94. https://doi.org/10.1353/sof.2006.0003

Cowser, A. (2013). Power and democracy in post-conflict Namibia: A case study of the Shack Dwellers Federation of Namibia. Saarbrucken: Scholars Press.

Cowser, A., \& Barnes, S. (2016). From shack dweller to home owner: The power of the MBOP, Africana womanism, and self-help housing among the Shack Dwellers Federation of Namibia. Journal of Namibian Studies, 19, 15-41.

Berg, B. L. (2009). Qualitative research methods for the social sciences (7th ed.). Boston, MA: Allyn and Bacon.

Buys, G. L., \& Nambala, S. V. V. (2003). History of the church in Namibia: An introduction. Windhoek: Gamsberg Macmillan.

Bystydzienski, J., \& Sekhon, E. (Eds.) (1999). Democratization and women's grassroots movements. Bloomington, IN: Indiana University Press. https://doi.org/10.2307/j.ctt1zxxxx5

Chambers, E. (2004). Roots for radicals: Organizing for power, action, and justice. New York: Continuum.

Chen, M., Jhabvala, R., Kanbur, R., \& Richards, C. (Eds.) (2007). Membership-based Organizations of the Poor. London: Routledge Press.

Christens, B. (2010). Public relationship building in power-based organizing: Relational intervention for individual and systems change. Journal of Community Psychology, 38, 886-900. https://doi.org/10.1002/jcop.20403

CIA World Factbook. (2016). Retrieved from www.ciaworldfactbook

Collins, P. H. (1998). Fighting words: Black women and the search for justice. Minneapolis, MN: University of Minnesota Press.

(2000). Black feminist thought: Knowledge, consciousness, and the politics of empowerment. New York: Routledge. 
Falola, T., \& Bridget, T. (2013). The power of gender, the gender of power: Women's labor, rights and responsibilities in Africa. Trenton, NJ: Africa World Press.

Harpending, H., \& Pennington, R. (1990). Herero households. Human Ecology, 18(4), 417-437. https://doi.org/10.1007/BF00889466

Hishongwa, N. (1983). Women of Namibia: The changing role of namibian women from traditional precolonial times to the present. Sweden: Forlaget by Oct Bygd.

HIV/AIDS in Namibia. (2012). Retrieved from http://hivinsite.ucsf.edu/global?page $=$ cr09-wa-00

HIV/AIDS in Namibia. (2013). Retrieved from http://www.cdc.gov/globalaids/Global-HIV-AIDS-at-CDC/countries/Namibia/default.ht $\mathrm{ml}$

Iipinge, E., \& Lebeau, D. (2005). Beyond inequalities: 2005 - women in Namibia. Windhoek: University of Namibia.

Iken, A. (1999). Women-headed households in southern Namibia: causes, patterns, and consequences. Windhoek: Gamsberg Macmillan.

Krippendorf, K. (1980). Content analysis: An introduction to its methodology. Beverly Hills, CA: Sage Publications.

Lincoln, C. E., \& Mamiya, L. (1990). The black church in the African-American experience. Durham: Duke University Press. https://doi.org/10.1215/9780822381648

Long, J. S., \& Freese, J. (2001). Regression models for categorical dependent variables using stata. College Station, TX: Stata Press.

Loubser, J. A. (1987). A critical review of racial theology in South Africa: The apartheid bible. Lewiston: The Edwin Mellen Press.

Maparyan, L. (2012). The womanist Idea. London: Routledge Press. https://doi.org/10.4324/9780203135938

Ministry of Health \& Social Services. (2009). HIV/AIDS in Namibia: Behavioral and contextual factors driving the epidemic: Measure evaluation \& USAID.

Mitlin, D., \& Satterthwaite, S. (2004). Empowering squatter citizen: Local government, civil society and urban poverty reduction. London: Earthscan.

National Planning Commission, Poverty and Deprivation in Namibia Report. (2015). Retrieved from http://www.npc.gov.na

Nederduitse Gereformeerde Kerk. (1976). Human relations and the South African scene in the light of scripture. Cape Town: Dutch Reformed Church Publishers.

Ngunjiri, F. W. (2010). Women's spiritual leadership in Africa: Tempered radicals and critical servant leaders. Albany, NY: State University of New York Press. 
Pattillo-McCoy, M. (1998). Church culture as a strategy of action in the black community. American Sociological Review, 63, 767-84. https://doi.org/10.2307/2657500

Paxton, P., \& Hughes, M. (2014). Women, politics, and power: A global perspective. Thousand Oaks, CA: Sage Publications.

Ruben, B. (2006). What leaders need to know and do: A leadership competencies scorecard. Washington, DC: National Association of College and University Business Officers.

Shack Dwellers Federation of Namibia. (2016). Shack Dwellers News, News Sheet (December). Windhoek: NHAG/HRDC.

Smock, K. (2004). Approaches to community organizing and their relationship to consensus organizing. New York: Columbia University Press.

Stall, S., \& Stoecker, R. (1997). Community organizing or organizing community? Gender and the crafts of empowerment. https://doi.org/10.1177/089124398012006008

Totemeyer, G. (2010). Church and state in Namibia. The politics of reconciliation. Freiburg: Arnold-Bergstraesser Institute.

Tripp, A. M., Casimiro, I., Kwesiga, J., \& Mungwa, A. (2009). African women's movements: Changing political landscapes. New York: Cambridge University Press.

Tvedten, I. (2011). 'As long as they don't bury me here': Social relations of poverty in a namibian shantytown. Switzerland: Basler Afrika Bibliographien. https://doi.org/10.2307/j.ctvh9vvsg

United Nations Development Programme. (2015). Summary of poverty and deprivation in Namibia. Retrieved from http://www.na.undp.org/content/namibia/en/home/library/poverty/nimdpovmao2015.ht $\mathrm{ml}$

Williams, P. (2014). I would have never...: A critical examination of women's agency for food security through participatory action research. In J. Page-Reeves (Ed.), Women redefining the Experience of food insecurity: Life off the edge of the table, (pp. 275-313). Lanham, MD: Lexington Books.

World Health Organization (2009). Retrieved 9 July, 2009 from http://www.who.int/features/2009/hiv_namibia/en/index.htm

\section{Appendix: Survey Questions and Variable Operationalizations (9 variables total)}

$\underline{\text { Religious Affiliation }}$

1. Religious Affiliation (three categories, Mainline; Gospel/Pentecostal/Apostolic; and Catholic, Mainline is the reference category): Q: What is the name of your church (coded into religious affiliations)? 
Language/Ethnicity (4 variables)

2. Ethnicity (four 0-1 dummy variables, Nama-Damara, Oshiwambo, Otjiherero, and Coloreds. Other is the reference group.): Q: What language do you speak (used to identify ethnicity)?

\section{Controls (2 variables)}

3. Education (0-1 dummy variable, post-Bantu): Q: What is your highest grade? [Missionary/Pre-Bantu (basic skills, equivalent to Grade 1-7 or below in the U.S.) and Post-Bantu (through Standard 10 or Grades 8-12)].

4. Years in the Federation (continuous variable, 1-15 years or more): Q: Year you joined the Federation (subtracted from 2010 to calculate tenure).

$\underline{\text { Reasons for Joining the Federation (2 variables) }}$

5. Reasons for Joining the Federation (two 0-1 dummy variables):

Why did you join the Federation (Please check all that apply)? Leadership development, reconciliation work, land tenure, build a Federation house or build community.

Federation Meaning (1 variable)

6. What Federation Means to Respondents (0-1 dummy variable): Q: What does the Federation mean to you?

\section{Narrative Questions}

7. Are you saving for your brick house, waiting for the land, building your brick house, or living in your brick house? (please circle answer)

8. Do you think that you are a community leader? If yes, why? If no, why not?

9. What are the good qualities of your leadership?

10. Describe one time when you were asked to solve a problem in the community.

11. Describe one time when your community came together to get something done (who, what, when, where, why, how).

12. What does the Federation mean to you?

13. How do your children feel about your Federation work? How is it helping them grow and develop?

14. How do you feel about women's rights - women's leadership?

15. What problems do you think the Federation faces? What needs to happen to achieve these changes? Can you help with that?

16. What needs do you see in the community besides housing?

17. What is your hope for the future? 
Federation 2010 data. Refer to Cowser (2013) for details.

\section{Notes}

Note 1. Community exchanges are local, regional, national and international organizing tools through which women learn, share and exchange information, experiences, and skills. Women also collect data (called enumerations) on the living conditions of shack dwellers that are used for community development and in negotiating with public officials.

Note 2. Since 2007, the Federation has completed profiles of 235 settlements in 30 Namibian areas about economic/housing conditions that is used to negotiate with public officials for resources.

Note 3. Funds from the Namibian government, Federasi repayments, and international foundations enable Federasi to borrow money to start small businesses (1,556 loans to date), get house loans (2,883 loans) and other services (1,406 loans). Most houses have 2 rooms measuring 34 square meters and cost about $\$ 24,000$ per house. Homeowners build and install their own water and sewer services incrementally based on the household's ability to pay for materials and services.

Note 4. For example, in the 1960 Cottesloe meeting of World Council of Churches delegates, total racial segregation in church and politics became a moral imperative. Human Relations and the South African Scene in the Light of Scripture (1976) provided a theological defense of apartheid.

Note 5. The Evangelical Lutheran Church in the Republic of Namibia (ELCRN), the Methodist Church, the Anglican Church, the AME Church, and the Uniting Reformed Church all ordain women.

Note 6. Preliminary modeling included controls for age (continuous variable, 0-70 or more), number of dependents (continuous variable, 0-25 or more), and employment status (0-1 dummy variable, wage employed). However, due to correlation and power issues, they were omitted from the final models. We contend that the remaining two controls capture key socioeconomic features.

Note 7. Several comments on causal ordering are in order. A strong argument can be made that certain independent variables such as ethnicity (language, place of residence, and customs) preceded our dependent variable, religious affiliation. A similar stance can be made for educational attainment. However, it is possible that Federasi joined the organization before, concomitant to, or after their religious involvement. We cannot definitively determine this ordering based on the questions posed. Yet we support our causal ordering choices because: existing qualitative and/or anecdotal work supports our choices; our focus on religious affiliations, rather than the depth and scope of such relationships; and, the exploratory nature of certain aspects of the study as possibly the first quantitative analysis on this topic. Thus this analysis reflects the above noted causal ordering, but also acknowledges the possibility of other possible causal processes for several of the independent variables. 


\section{Al Macrothink}

Note 8. Although the concept is not used in the U.S., Coloreds is an ethnic grouping in Namibia and includes Namibians from varied historic locales. Although they may speak other languages, they speak Afrikaans primarily rather than their indigenous language(s), live in urban rather than rural areas, and tend to interact with whites more frequently. Some are relatively more economically stable than other black Namibians (Cowser, 2013).

Note 9. Data were collected by the first author during a Fulbright internship. Twenty Federation meetings at local and regional levels, as well as five meetings between Federation members and municipal authorities were also observed. Given the challenges of outsiders to gain access to this population, this is not a random sample. Ovambos (who are Lutheran) are over-represented in the sample. Yet data were also collected in Kavangoland and Namaland. To audit the data, in July 2010, a meeting was held with the second author and about 30 Federation leaders at their Windhoek headquarters to present findings and solicit comments. These leaders vetted the data and results (Cowser, 2013).

Note 10. Surveys were usually completed after Federation meetings. Shorter completion times were usually the result of women with limited time after meetings. In these rare instances, responses are not as detailed as they could have been had more time been available. However, we believe that resulting responses represent issues of most importance to Federasi members because they were provided despite time constraints. Taped interviews were transcribed 5-21 days after collection, depending on field conditions. The questionnaire data were recorded in Excel spreadsheets upon return to the U.S.; the time between collection and entry of these data was 5-6 months. The $1^{\text {st }}$ author collected and, in collaboration with local translators, transcribed all data. The $2^{\text {nd }}$ author audited the data.

Note 11. In more remote villages and towns, translators were used for respondents who neither spoke nor were able to read English. In these cases, a questionnaire and pen/pencil were provided to each translator, who sat with each respondent and completed questionnaires face-to-face.

Note 12. The original sample includes 281 Federasi. However, 23 respondents did not provide a religious affiliation, so they were excluded from the analysis.

Note 13. "Other" also includes at least one Federasi from the following groups; Hai/Iom, Mbalangwe, Oshindonga, Otjimbundu, Otjimbundu, Ovambo, Rukwangali, Sifwe, Silozi, Subia, Tokela, Tswana, and Xhosa.

\section{Copyright Disclaimer}

Copyright for this article is retained by the author(s), with first publication rights granted to the journal.

This is an open-access article distributed under the terms and conditions of the Creative Commons Attribution license (http://creativecommons.org/licenses/by/3.0/). 